\begin{tabular}{|c|l|}
\hline Title & Economic impact of ocean acidification on shellfish production in Europe \\
\hline Author(s) & Narita, Daiju; Rehdanz, Katrin \\
\hline Citation & $\begin{array}{l}\text { Journal of environmental planning and management, 60/3), 500-518 } \\
\text { https://doi.org/10.1080/09640568.2016.1162705 }\end{array}$ \\
\hline Issue Date & 2017-03 \\
\hline Doc URL & http://hdl.handle.net/2115/68394 \\
\hline Rights & $\begin{array}{l}\text { This is an A ccepted Manuscript of an article published by Taylor \& Francis in Journal of environmental planning and } \\
\text { management on March 2017, available online: http://www.tandfonline.com/10.1080/09640568.2016.1162705. }\end{array}$ \\
\hline Type & article (author version) \\
\hline File Information & JEPM.pdf \\
\hline
\end{tabular}

Instructions for use 


\title{
Economic impact of ocean acidification on shellfish production in Europe
}

\begin{abstract}
Ocean acidification is increasingly recognized as a major global problem. Despite the scientific evidence, economic assessments of its effects are few. This analysis is an attempt of a national and sub-national assessment of the economic impact of ocean acidification on mollusk production in Europe. We focus on mollusk production because the scientific evidence on the biological impact on calcifying organisms is ample relative to other types of marine organisms. In addition, Europe and its regions are significant producers of marine mollusks. By performing a partial-equilibrium analysis, we show that the largest levels of overall impact are found in the countries with the largest current production such as France, Italy and Spain. For Europe as a whole the annual impact is over 1 billion USD in 2100. Due to the different production foci of the individual countries and their regions, the distribution of the impact is very uneven across countries and also country regions, with the most affected subnational regions being those at the Atlantic coast of France, which are a location of significant oyster production.
\end{abstract}

Key Words: Climate change, economic assessment, Europe, ocean acidification, shellfish

\section{Introduction}

Described as "the other $\mathrm{CO}_{2}$ problem" (Doney et al., 2009), ocean acidification (OA) is gaining recognition in the policy debates of climate change and biodiversity (e.g., Secretariat of the Convention on Biological Diversity, 2014). Governed by a well-known law of chemical equilibrium, enhanced atmospheric carbon dioxide due to human emissions shifts the balance of carbonate ions in seawater and lowers the $\mathrm{pH}$ of the ocean. Since atmospheric carbon dioxide is evenly mixed around the world, OA is a global problem, though some regional heterogeneity of effects exists because of the differences in ocean circulations, ocean temperatures and evaporation rates. Early calculations indicate that the global average $\mathrm{pH}$ of surface seawater (around 8.1) would be reduced by $0.3-0.4$ by the end of the 21 st century under the business-as-usual emission path (Caldeira and Wickett, 2003, 2005). The latest IPCC Assessment Report (2014) concludes that under its medium to high emission scenarios, OA could pose detrimental consequences on fisheries and livelihoods.

Along with natural scientific research of $\mathrm{OA}$, attempts are being made as to economic analysis of OA, which focuses on damages on shell fisheries and ecosystem services provided by coral reefs (including recreation/tourism opportunities, coastal protection and reef related fisheries evaluated in monetary units (Brander et al., 2014 review the literature of economic analysis of $\mathrm{OA})$. Economic assessment of OA is useful for the following reasons. First, estimation of potential economic damages of OA could help policymakers plan investments for developing adaptation options in anticipation of future effects. Second, as OA occurs along with climate change as a result of human carbon dioxide emissions, economic assessment of its impacts is needed for accurate estimation of the social cost of carbon ${ }^{1}$ to provide a basis for global debates of climate change mitigation. Significant economic costs of OA would imply that the optimal mix of greenhouse gases reduction could not be evaluated by their relative

\footnotetext{
${ }^{1}$ As a government initiative, the US government already estimates the social cost of carbon (i.e., the value of economic damages associated with a unit increase in carbon dioxide emissions) for its appraisal of government projects (Interagency Working Group on Social Cost of Carbon, 2013).
} 
atmospheric warming potentials only. It is also worth noting that estimating the relative impacts of OA could have particular implications for devising strategies of climate change mitigation, as some measures of climate (or geo-) engineering such as solar radiation management are not effective for controlling OA (Williamson and Turley, 2012).

Scientific information about biological and ecological impacts of OA on marine organisms is still very limited, and thus quantitative economic studies of OA are so far focused on types of marine organisms on which the effects of acidification are relatively known, namely, on corals and mollusks (see Brander et al., 2014 for a review). Brander et al. (2012) attempt a global economic assessment of ecosystem services of coral reefs under OA by using an integrated assessment model of climate change (FUND model), where ecosystem services of coral reefs are considered to be largely recreational services. Cooley and Doney (2009) estimates losses of US mollusk fisheries under OA by assuming damages for the industry proportional to the calcification loss rates of mollusks reported in the literature of biological experiments under acidified environments. Narita et al. (2012) conduct a global analysis that also estimates damages as proportional to the calcification loss rates taken from a meta-study but is based on a partial-equilibrium approach that could take into account the effects of price shifts. Though backed up with only limited empirical information, Moore (2015) is an attempt of complete welfare analysis of mollusk production and consumption under OA that considers an expenditure function of the representative household in the US. A related group of studies to those economic assessments is the studies of vulnerabilities of fisheries to OA (Cooley et al, 2012; Ekstrom et al., 2015). Refraining from the use of economic projections, they have the advantage of basing their analysis only on solid natural-scientific data. While their results could be useful for identifying near-term adaptation strategies of fisheries to OA, their analyses do not show the values of OA losses explicitly and thus are not directly relatable to the debates of climate change mitigation policies. It is also worth noting that some reference to economic projections is inevitable for reflecting on long-term strategies of both mitigation and adaptation, as the production of shellfish is determined not only by conditions of the marine environment but also by its demand.

This paper contributes to the existing literature by focusing on the economic impact of OA on shellfish production in Europe and its sub-national regions. In Europe, as compared to other regions, the status of policy discussions of OA is relatively advanced (see e.g. Hilmi et al. 2014). Our results are, therefore, of direct policy relevance. Furthermore, and as pointed out above, earlier studies have looked at the global economic impacts (e.g., Narita et al. 2012) or a specific country (e.g., Moore 2015). So far, no study investigates country regions with a comparison of individual countries. Europe is particularly interesting for such a regional study because of its diversity in produced species (e.g., oysters in France and mussels on the continental North Sea coast) and in environmental conditions of marine waters across the region (see Hilmi et al. 2014 for ). In addition, Europe is the second largest producer of global aquaculture production of mollusks and the fourth largest producer of marine mollusks capture. $^{2}$ In our analysis we rely on the partial-equilibrium approach and estimate country specific and sub-national economic costs of production loss of mollusks (impacts both on producer and consumer surpluses) due to OA in 2100 under a business-as-usual emission scenario.

The paper is structured as follows. Section 2 briefly summarizes the scientific facts of OA that serve as the basis for our analysis and provides information on the state of the European economy regarding consumption and production of shellfish in Europe. Section 3 presents our

\footnotetext{
${ }^{2}$ For example, according to the FAO statistics, the share of Europe in global aquaculture production of mollusks is $9 \%$ in 2010 .
} 
approach of partial-equilibrium analysis and the data that we use. Section 4 shows results and Section 5 concludes.

\section{Biological impacts and the state of the economy}

\subsection{Biological impacts}

OA could harm the growth and survival of marine organisms through both direct (i.e., through disturbance of physiological processes) and indirect (i.e., through changes in ecological interactions) effects (IPCC, 2011). Biological research on this subject is only emerging, but a relatively large amount of information exists for direct effects of acidified water on calcifying organisms, such as mollusks and corals. Recent meta-studies find that direct negative effects are significant at least for mollusks (Hendriks et al., 2010; Kroeker et al., 2010, 2013). A caveat for this finding is that those studies are based on only short-term experiments and also that the magnitude (and possibly, also the sign) of those effects can be different across the species of mollusks (Wittmann and Pörtner, 2013). Meanwhile, indirect effects of OA and its combination with other stressors for marine organisms (ocean warming, habitat destruction, overexploitation, eutrophication and other forms of chemical pollution, invasive species) could exert potentially serious, though still largely unknown, negative effects (IPCC, 2011).

Although research evidence is even scarcer, there are some indications that many biological functions other than calcification could also be affected by OA, and consequently that direct effects of acidification may appear on a wide range of organisms, from fish to bacteria (IPCC, 2011; Hilmi et al., 2013). At the same time, however, it is also known that some marine organisms, such as phytoplanktons and some seagrass species, could benefit from low $\mathrm{pH}$ levels and thus potentially thrive under OA (IPCC, 2011; Hilmi et al., 2013).

\subsection{State of the economy}

Before turning to the quantitative assessment of the impact of OA in Europe, we explore the state of the European economies regarding shellfish consumption, production and employment. We do so in particular to investigate if regional differences are likely to exist that matter in terms of impact assessment. For the Mediterranean countries, Hilmi et al. (2014) also summarize fisheries statistics with a similar scope to ours.

Table 1 shows average annual consumption of total seafood and mollusks in European countries for the period 2001-2010. The consumption patterns of mollusks indicate large heterogeneity across European countries. Most countries have small per capita consumption with less than $1 \mathrm{~kg}$ per year, but a few countries, such as Belgium, Denmark, Iceland, Italy and Portugal (with over $3 \mathrm{~kg}$ per capita per year) as well as Spain and France (with over $6 \mathrm{~kg}$ per capita per year), exhibit significantly larger amounts of per capita consumption. The Table also shows that some countries with high seafood consumption in general do not consume large amounts of mollusks (such as Iceland, Norway and Lithuania). 
Turning to the production of mollusks in European countries, Table 2 indicates that also for average annual production large heterogeneity across European countries exists for the period 2001-2010. The majority of countries produced less than 10,000 tons of mollusks per year during that period. However, exceptions are the Netherlands, Spain and France with a production above 100,000 tons; the latter country being even close to 200,000 tons. Turning to the group of species produced, mussel production clearly dominates. For most countries more than half of their mollusk production is allocated to mussels. Among the countries with significant mollusk production, France is the only one with a large share of oyster production. The percentage of clams, cockles and arkshells is overall rather negligible.

Looking at the type of production used, also here significant differences exist across Europe (Table 2). However, most of the countries with significant mollusk production ( $>10,000$ tons) use predominantly aquaculture techniques (France, Germany, Greece, Ireland, the Netherlands and Spain) while countries including Denmark and the UK rely on capture fisheries for mollusk production.

\section{Table 2 about here}

Overall, these first insights highlight that the impact of OA on consumers and producers will be very differently distributed across Europe. It seems, for example, not necessarily the case that mollusks are consumed where they are produced. Households in the Netherlands consume relatively little despite the significant production there. Table 3 confirms this by providing information on average annual trade quantities and values for the period 2001-2010. A positive (negative) sign indicates an export (import) surplus. For countries like Spain, Denmark, Ireland and the Netherlands the value of net exports of mussels exceeds 10 million USD per year; the latter country being even close to 100 million USD per year. France is a significant net exporter of oysters and clams, cockles and arkshells (annual value over 10 million USD) but also a significant net importer of mussels (annual value over 88 million USD). Interestingly, Italy and Germany produce significant amounts of marine mussels (Table 2) but are large net importers (annual value over 10 million USD and 43 million USD; respectively).

\section{Table 3 about here}

Employment of the fishery sector shows large heterogeneity across countries of Europe (data are shown in Table A1 in the Appendix). Employment is low in some countries, e.g., in Belgium where there are only a few hundred fishers. Other countries have higher employment, with Greece, Italy and Spain possessing the largest numbers of fishers (over 20,000). In all countries of Europe, however, the total size of employment in the fishery sector is in the order of 10,000 persons at most and declining for decades, hence any loss of employment in the sector as a result of OA would have only a negligible macroeconomic impact. ${ }^{3}$

\footnotetext{
${ }^{3}$ To be sure, capture and aquaculture fisheries involve various secondary activities such as seafood processing and could create employment also there. According to one estimate, employment of one person in the capture or aquaculture activities creates on average four jobs in the secondary activities (FAO, 2008: as cited by Hilmi et al., 2014) . But macroeconomic impacts of fisheries-related employment would be small even including those secondary activities.
} 
The top three nations in terms of employment are France, Spain and Italy. Greece is a prominent country in fisheries in general but does not have a large sector of mollusk aquaculture. Mollusk aquaculture in France is larger in the size of employment than the total capture fisheries (mollusks and also others), but it is not the case in Spain and Italy. European Commission Joint Research Centre (2013) reports that the mollusk aquaculture in France mainly grows Pacific cupped oyster (Crassostrea gigas), blue mussel (Mytilus edulis), and Mediterranean mussel (Mytilus galloprovincialis) whereas the main species of cultivation in Spain are Mediterranean mussel, and Venus clams and Mediterranean mussel in Italy.

\section{Quantitative assessment}

As noted in the previous section, actual impacts of OA on mollusks are likely to appear as a result of complex interactions with various other stressors and ecosystem functions, but in this analysis we attempt a simple and transparent estimation that could be used as benchmarks. To this end, we use as the basis of acidification loss the information of biological experiments, which is solid relative to other types of information (e.g., information from the actual events of raised water acidity in the natural environment, which is little). Kroeker et al. (2013) reports estimates of four measures regarding the damage of OA on mollusks: survival, calcification, growth and development. Out of those four estimates, we adopt the value of calcification loss (40\%), the largest in effect size among the four, and the value of growth loss $(17 \%)$, the smallest, for our analysis. On the one hand, the actual loss of production could be smaller than those figures of calcification and growth losses if mollusks with lower levels of calcification and growth under OA are still marketable as seafood. On the other hand, it is also possible that our use of the calcification and growth loss rates as a proxy for production loss could result in underestimation of the impacts if both ways of damage occur independently to individuals.

Kroeker et al.'s meta-study level data are not sufficient for identifying distinct effects on different species of mollusks, and consequently we do not consider heterogeneous impacts of OA by species. This is likely to be oversimplification, but scientific information is still lacking about how different impacts are across different species of commercial importance (Hilmi et al., 2014). Also, our analysis has limitations not to reflect the combined effects of OA and temperature change, because the information of the combined effects on mollusks is lacking on a meta-study level.

A large fraction of mollusk fisheries today concerns aquaculture. In some of the cases we consider, we distinguish mollusk production from capture fisheries and aquaculture, which might have different responses to OA. Aquaculture, which utilizes a controlled water environment, could in principle insulate itself from the effects of OA by manipulating the acidity of cultivating water. However, as mollusks feed on planktons commonly found in open marine environments, practices of mollusk aquaculture normally involve some period of cultivation in open water. Hence, staving off a higher acidity of seawater is likely to add extra costs to aquaculture, if not making it impossible. Billé et al. (2013) discuss possibilities of adaptation for fisheries management under OA. In any event, there is a strong reason to assume that not only capture fisheries but also aquaculture of mollusks are affected by acidification. In this analysis, we simply assume that the effect of acidification equally falls on capture fisheries and aquaculture. 
As for production quantities of mollusks, we base our estimates on data provided by the FAO Fisheries and Aquaculture Department. ${ }^{4}$ Annual information on total aquaculture and capture production by country is obtained for the period 2001-2010. The FAO database contains data of aquaculture production in value (in USD) by country and species. Our aquaculture dataset covers 54 gastropod and bivalve species belonging to the following six species groups: "abalones, winkles and conches," "oysters," "mussels," "scallops and pectinids," "clams, cockles, and arkshells," and "marine molluscs nei, other." Meanwhile, the FAO database does not include data on capture production in value (it has only volume data). In other words, the value data provided by the FAO are not directly usable for our analysis since they neglect the value of mollusks from capture fisheries. To compensate this insufficiency of the FAO data on capture we assume that prices for capture and aquaculture are the same for the identical species and estimate the values of captured mollusks by using the imputed prices from the value and quantity data of mollusk aquaculture from the FAO database. Also, to supplement the analysis on the country level with an analysis on the subnational level, we use the Sea Around Us database that provides subnational information on aquaculture production quantities for mollusk species. ${ }^{6,7}$ By using this data we assume that the regional share of mollusk capture production in a country is equivalent to the regional share of aquaculture production for a species group. Further information on the subnational analysis is provided below. Note that our dataset of mollusk fisheries does not include values of recreational fisheries, for which few data exist but whose levels are presumed to be high (Hilmi et al., 2014).

We estimate losses of OA by using two methodological approaches. The one is a simple multiplication (coded as "simple" in our cases) of the total value of mollusk production and a loss rate (i.e., without price effects), which has the benefit of simplicity and clarity but does not reflect potential changes in demand of mollusks through the price adjustment from shifts in supply under OA. The other is a partial-equilibrium model ("parteq") previously used by Narita et al. (2012). A partial equilibrium approach captures the effect of a potential price shift due to the tightening of supply from OA and could show how the losses would be distributed between producers and consumers. The market of mollusks is represented with demand and supply curves, and OA is assumed to shift the supply curve (uniformly) leftward. The slopes of the demand and (current) supply functions are set to be consistent with representative values of demand and supply elasticities of mollusks. We use the same values of elasticities as in Narita et al. (2012), which draw on parameter values of the IMPACT model by the International Food Policy Research Institute (IFPRI) ${ }^{8}$. A graphical representation of our partial equilibrium model is shown in the Appendix (Figure A2).

We also examine two sets of cases in which the demand of mollusks is kept at the current level and is enhanced according to income growth in the future. Based on IPCC's RCP 8.5 scenario, the levels of OA considered in Kroeker et al.'s meta-study broadly correspond to the levels for the year 2100. Hence, we estimate and present figures as the losses of mollusk

\footnotetext{
${ }_{5}^{4}$ http://www.fao.org/fishery/statistics/en.

${ }^{5}$ The FAO dataset contains another category of mollusks, "freshwater mollusks." We excluded this category from our analysis because it is not clear whether ocean acidification could cause any effect on freshwater organisms.

${ }^{6} \mathrm{http}: / /$ www.seaaroundus.org/

${ }^{7}$ Cephalopods (octopuses, squids, etc.) are excluded from this category.

${ }^{8}$ The supply elasticity is 0.2 for Eastern European and Former Soviet Union countries, and 0.4 for Western European countries. The demand elasticity is 1.01 for Former Soviet Union countries, 0.97 for Eastern European countries, and 0.91 for Western European countries.
} 
production due to OA in the year 2100 relative to the cases without OA. ${ }^{9}$ This choice of time point is not ideal for the results to be related to the discussions of near-term adaptation of mollusk fisheries since it is far in the future, but it is rather convenient for the discussions of climate change mitigation policies.

As for IPCC's RCP 8.5, the scenario itself does not specify GDP figures, but as RCP 8.5 scenario is an extension of IPCC's A2 scenario (Riahi et al., 2011), we use country breakdown figures of the global GDP values of the A2 scenario estimated by Van Vuuren (2007) and Gaffin et al. (2004) (coded as "V" and "G" in our cases). Setting the year 2005 (the mid-year of the averaging period) as the base year, we calculate the income growth of individual countries from that year to the year 2100 and then increases in the demand of mollusks by using the income elasticity figures used in Narita et al. (2012), which originally come from the IMPACT model. ${ }^{10}$

\section{Results}

Figure 1 displays the estimated annual economic loss (i.e., the decrease from the baseline without OA) in Europe in 2100 due to damage on mollusk production under OA. As mentioned in the previous section, we estimate values using the basis of the estimated calcification loss and growth loss rates (coded as "calci" and "growth," respectively). A simple estimate of loss without taking into account the effects of future income growth and price adjustments yields 0.67 billion USD annually, 55\% of which ( 0.37 billion USD) comes from loss of aquaculture (results not shown). With the income and price effects included, the total loss in Europe amounts to nearly 1 billion USD annually (parteq_calci_V). The estimated loss is much lower when the growth loss rate is used instead of the calcification loss rate (simple_growth). This is true for all cases of estimation. When considering future income growth, the impact significantly increases for all cases of estimation. In general, the levels of loss vary significantly depending on the basis of income projection, despite the fact that the two datasets used here are country-level decompositions of the same IPCC scenario: the effect is much more pronounced when using the Van Vuuren data compared to the Griffin et al. data (as an example compare simple_calci_V and simple_calci_G). When comparing the simple multiplication and the comprehensive partial equilibrium approach, the loss is larger for the more encompassing partial equilibrium approach (as an example compare simple_calci_V and parteq_calci_V), reflecting the price mechanism that adjusts the demand of mollusks. These are general findings. Also, the loss of consumer surplus is generally slightly greater than the loss of producer surplus, in other words, the consumers suffer slightly more than the producers from acidification (results not shown).

\section{Figure 1 about here}

On the national level, large differences exist. Figure 2 shows the estimated annual economic loss in 2100 in selected European countries due to damage on mollusk production under OA. Irrespective of the scenario, France incurs by far the largest loss, followed by Italy, the UK and Spain. Loss for France is 0.27 billion USD in the estimation without price and income

\footnotetext{
${ }^{9}$ The $\mathrm{pH}$ levels of European waters show some regional heterogeneity (see Figure A1 in the Appendix), but because of the limited information of the meta study on biological impacts, the following analysis does not reflect different levels of $\mathrm{pH}$ change across areas.

${ }^{10}$ The income elasticity is 0.55 for Former Soviet Union countries, 0.45 for Eastern European countries, and 0.35 for Western European countries.
} 
effects (simple_calci) and 0.39 billion USD in the estimation with those two effects (parteq_calci_V').

\section{Figure 2 about here}

As for distinguished impacts for aquaculture and capture mollusk production (shown in Figure A3 in the Appendix), production of mussels is dominated by aquaculture and production of oysters nearly exclusively comes from aquaculture. Loss of mussel production is 0.22 billion USDin the estimation without price and income effects and 0.33 billion USD in the estimation with those effects. Aquaculture is dominant in France and Spain, whereas capture is dominant in the UK.

Figure 3 extends the analysis by providing information on the estimated annual economic loss by country and species groups (parteq_calci_V scenario). The size of the circles displays the extent of the loss while the division indicates the distribution of economic loss across the three species groups. Following Figure 3, the overall impact is largest in France, Italy and Spain (over 0.1 billion USD), but also in the UK, Denmark and the Netherlands the impact is large (between 0.06 and 0.1 billion USD).

Focusing on the distribution of the impact across species groups, impacts are not evenly distributed across groups. Among the three groups of species, in France net losses are largest for oysters ( 0.23 billion USD), while in the Netherlands, Denmark, Ireland and Spain the impact is largest for mussels $(0.07,0.07,0.01$ and 0.05 billion USD respectively); in Italy, Portugal and the UK the impact on clams, cockles and arkshells dominate $(0.07,0.03$ and 0.02 billion USD respectively).

\section{Figure 3 about here}

Overall, the results so far have demonstrated that large heterogeneity across European countries exists regarding the economic impact of OA on mollusk production. Furthermore, and especially due to the different production foci within these countries, the distribution of the impact is very uneven across countries. However, heterogeneity not only exists across countries but also within countries. To take this into account we use our results for an analysis on the subnational level.

Figure 4 displays the estimated annual economic loss by region for oysters (parteq_calci_V scenario). From above we know that losses are unevenly distributed across countries. Figure 4 suggests the same for the subnational level. Some regions will suffer more than others. France is the country with the by far largest production of oysters and according to Figures 2 and 3 above the country with the largest impact on oyster production. Its production comes mostly from aquaculture, and this means that finding adaptation methods of aquaculture practices to OA would greatly reduce the level of the total potential loss. At the subnational-level, a similar pattern emerges. Regions in France (for which we have data) will be affected more heavily than almost any of the other regions in Europe. Three regions in France seem particularly vulnerable: Poitou-Charentes, Basse-Normandie and Southern Bretagne (about 89, 44 and 30 million USD). The only other subnational regions within Europe (for which we 
have data) with significant impacts include Galicia in Spain, Zeeland in the Netherlands and Attica in Greece.

\section{Figure 4 about here}

Figure 5 displays the estimated annual economic loss by region for mussels (parteq_calci_V scenario). Again, we find large differences between regions. Unlike oyster production, which is concentrated in France, there are many more countries in Europe that contribute significantly to the mussel production of Europe; the Netherlands, Denmark, France, Italy and Spain (Figure 3). For the Netherlands, all regions are heavily affected, but the ones in the South slightly more so (about 34 million USD in Zeeland). For Denmark the impact is larger for regions on the West Coast. For Spain, the impact is largest in regions at the North Atlantic (Galicia) and much less pronounced in regions at the Mediterranean Sea. For France this difference is less clear. Differences between regions in Italy seem not very pronounced.

\section{Figure 5 about here}

\section{Discussion and conclusion}

This analysis is an attempt of a national and sub-national assessment of the economic impact of OA on mollusk production in Europe. We focus on mollusk production because the scientific evidence on the biological impact on calcifying organisms is ample relative to other types of marine organisms. In addition, Europe and its regions are significant producers of marine mollusks.

Our results show that the largest levels of overall impact are found in the countries with the largest current production such as France, Italy and Spain. For Europe as a whole the impact is over 1 billion USD annually in 2100. Due to the different production foci of the individual countries and their regions, the distribution of the impact is very uneven across countries and also country regions. According to our scenario analysis subnational regions most affected are regions at the Atlantic coast of France significantly contributing to oyster production.

The figures we obtained are broadly consistent with the estimates by other studies, despite differences in methodology. Moore (2015) estimates the annual consumer welfare impacts of mollusk loss due to OA in the US to become about 440 million USD by the end of the century, by using the basis of 431 million USD of US expenditure on mollusks in 2010. Our analysis also shows similar closeness in the order between the 2100 loss in consumer surplus $(0.6$ billion USD for parteq_calci_V) and the baseline level of mollusk production (1.7 billion USD) in Europe. Meanwhile, Armstrong et al.'s (2012) scoping study on Norway shows that OA may bring about 74 million Norwegian Krone (about 9.6 million USD) of loss in provisioning services (including the provisioning of seafood) in 2110 (worst case with $0 \%$ discount rate) without including the income effect. In our analysis, a loss of 7 million USD for Norway in 2100 is estimated for a case without income and price effects considered (simple_calci).

As expected, our estimates are small compared to the estimates of the total economic costs of climate change: most integrated assessment models predict greater than $1 \%$ of total GDP loss globally with a significant increase (i.e., $>2{ }^{\circ} \mathrm{C}$ ) of the global average surface temperature 
(Tol, 2009, 2014), whereas the global total GDP is 76 trillion USD at present (the 2013 value in current USD according to World Development Indicators). However, it needs to be noted that we look only at a relatively small sector within fisheries, mollusk production. The total impact of OA on fisheries could be much greater than our estimate. Moreover, the ocean provides values more than those associated with fisheries, including recreational values and symbolic values of marine environments and organisms, and these non-fishery functions of the ocean will also be affected by OA.

Estimation of economic losses of OA in concrete numbers like this study's has the advantage of being usable for various types of discussions, including those of climate change mitigation policies. However, the scarcity of scientific data on OA poses limitations to our analysis in various ways, such as our singular focus on a year in a distant future (the year 2100). Deeper accumulation of scientific evidence would improve the accuracy of a similar analysis and also the usefulness of obtained estimates. Data of differentiated impacts by species and $\mathrm{pH}$ level at a meta-study level would be beneficial for economic assessment, as well as the data on combined effects of $\mathrm{pH}$ and other stressors (e.g., $\mathrm{pH}+$ temperature). Indeed, European waters exhibit substantial regional differences in changes in $\mathrm{pH}$ and ocean temperature. Also, economic assessment would benefit from information of biological impacts evaluated in the actual ecosystems rather than in the laboratory environment. Listing up these shortcomings in scientific evidence does not mean that the limitations are only attributable to natural science for one thing, better economic information about income and price dependency of shellfish demand would improve the assessment. Our study highlights the needs for future research.

\section{References}

Armstrong, C.W., S. Holen, S. Navrud, and I. Seifert, 2012. The economics of ocean acidification: A scoping study.

Billé, R., R. Kelly, A. Biastoch, E. Harrould-Kolieb, D. Herr, F. Joos, K. Kroeker, D. Laffoley, A. Oschlies, and J.-P. Gattuso, 2013. Taking action against ocean acidification: A review of management and policy options, Environmental Management 52: 761-779.

Brander, L.M., K. Rehdanz, R.S.J. Tol, and P. van Beukering, 2012. The economic impact of ocean acidification on coral reefs, Climate Change Economics, 3(1), 1250002.

Brander, L.M., D. Narita, K. Rehdanz, and R.S.J. Tol, 2014. The economic impacts of ocean acidification, in P.A.L.D. Nunes, P. Kumar, and T. Dedeurwaerdere (eds.) Handbook on the Economics of Ecosystem Services and Biodiversity, Cheltenham, UK: Edward Elgar.

Caldeira, K., M.E. Wickett, 2003. Anthropogenic carbon and ocean pH, Nature 425: 365.

Caldeira, K., M.E. Wickett, 2005. Ocean model predictions of chemistry changes from carbon dioxide emissions to the atmosphere and ocean, Journal of Geophysical Research 110: C09S04.

Cooley, S.R., and S.C. Doney, 2009. Anticipating ocean acidification's economic consequences for commercial fisheries, Environmental Research Letters, 4, 024007.

Cooley, S.R., N. Lucey, H. Kite-Powell, and S.C. Doney, 2012. Nutrition and income from molluscs today imply vulnerability to OA tomorrow, Fish and Fisheries 13(2): 182-215.

Doney, S.C., V.J. Fabry, R.A. Feely and J.A. Kleypas, 2009. Ocean acidification: the other CO2 problem, Annual Review of Marine Science 1: 169-192.

Ekstrom, J.A., L. Suatoni, S.R. Cooley, L.H. Pendleton, G.G. Waldbusser, J.E. Cinner, J. Ritter, C. Langdon, R. van Hooidonk, D. Gledhill, K. Wellman, M.W. Beck, L.M. Brander, D. 
Rittschof, C. Doherty, P.E.T. Edwards, and R. Portela, 2015. Vulnerability and adaptation of US shellfisheries to ocean acidification, Nature Climate Change 5: 207-214.

European Commission Joint Research Centre, 2013. The Economic Performance of the EU, Aquaculture Sector, Luxembourg: Publications Office of the European Union.

FAO, 2008. The State of World Fisheries and Aquaculture, Rome, Italy: FAO, p. 26.

Gaffin, S., C. Rosenzweig, X. Xing, and G. Yetman, 2004. Downscaling and geo-spatial gridding of socio-economic projections from the IPCC Special Report on Emissions Scenarios (SRES), Global Environmental Change 14(2): 105-123.

Hendriks, I.E., C.M. Duarte, and M. Álvarez, 2010. Vulnerability of marine biodiversity to ocean acidification: A meta-analysis, Estuarine, Coastal and Shelf Science 86(2): 157-164.

Hilmi , N., D. Allemand, S. Dupont, A. Safa, G. Haraldsson, P.A.L.D. Nunes, C. Moore, C. Hattam, S. Reynaud, J.M. Hall-Spencer, M. Fine, C. Turley, R. Jeffree, J. Orr, P.L. Munday, and S.R. Cooley, 2013. Towards improved socio-economic assessments of ocean acidification's impacts, Marine Biology 160:1773-1787.

Hilmi, N., D. Allemand, M. Cinar, S. Cooley, J. Hall-Spencer, G. Haraldsson, C. Hattam, R.A. Jeffree, J.C. Orr, K. Rehdanz, S. Reynaud, A. Safa and S. Dupont, 2014. Sensitivity of Mediterranean countries to ocean acidification, Water, 6, 1719-1744; doi:10.3390/w6061719.

Interagency Working Group on Social Cost of Carbon, 2013. Technical support document: Technical update of the social cost of carbon for regulatory impact analysis under Executive Order 12866.

Intergovernmental Panel on Climate Change (IPCC), 2011. Workshop Report of the IPCC Workshop on Impacts of Ocean Acidification on Marine Biology and Ecosystems, Field, C.B., V. Barros, T.F. Stocker, D. Qin, K.J. Mach, G.-K. Plattner, M.D. Mastrandrea, M. Tignor and K.L. Ebi (Eds.), IPCC Working Group II Technical Support Unit, Carnegie Institution, Stanford, California, United States of America, pp. 164.

Intergovernmental Panel on Climate Change (IPCC), 2014. Climate Change 2014: Impacts, Adaptation and Vulnerability.

Kroeker, K.J., R.L. Kordas, R.N. Crim, and G.G. Singh, 2010. Meta-analysis reveals negative yet variable effects of ocean acidification on marine organisms, Ecology Letters 13 (11): $1419-1434$.

Kroeker, K.J., R.L. Kordas, R. Crim, I.E. Hendriks, L. Ramajo, G.S. Singh, C.M. Duarte, and J.-P. Gattuso, 2013. Impacts of ocean acidification on marine organisms: Quantifying sensitivities and interaction with warming, Global Change Biology 19: 1884-1896.

Moore, C., 2015. Welfare Estimates of Avoided Ocean Acidification in the U.S. Mollusk Market, Journal of Agricultural and Resource Economics 40 (1): 50-62.

Narita, D., K. Rehdanz and R.S.J. Tol, 2012. Economic costs of ocean acidification: A look into the impacts on global shellfish production, Climatic Change 113: 1049-1063.

Riahi, K., S. Rao, V. Krey, C. Cho, V. Chirkov, G. Fischer, G. Kindermann, N. Nakicenovic and P. Rafaj, 2011. RCP 8.5 - A scenario of comparatively high greenhouse gas emissions, Climatic Change 109:33-57.

Secretariat of the Convention on Biological Diversity, 2014. An updated synthesis of the impacts of ocean acidification on marine biodiversity, CBD Technical Series No. 75.

Tol, R.S.J., 2009. The economic effects of climate change. Journal of Economic Perspectives 
23(2): $29-51$.

Tol, R.S J., 2014. Correction and update: The economic effects of climate change. Journal of Economic Perspectives, 28(2): 221-26.

Van Vuuren, D.P., P.L. Lucas, and H. Hilderink, 2007. Downscaling drivers of global environmental change: Enabling use of global SRES scenarios at the national and grid levels, Global Environmental Change 17: 114-130.

Williamson $\mathrm{P}$, . and C. Turley, 2012. Ocean acidification in a geoengineering context. Philosophical Transactions of the Royal Society A 370:4317-4342.

Wittmann, A.C. and H.-O. Pörtner, 2013. Sensitivities of extant animal taxa to ocean acidification, Nature Climate Change 3: 995-1001. 
Table 1. Average annual consumption of total seafood and mollusks in European countries (kg per year per capita; averaged over 2001-2010)

\begin{tabular}{|c|c|c|c|}
\hline Country & Total seafood ${ }^{1}$ & Mollusks $^{2}$ & $\begin{array}{c}\% \text { of mollusks to } \\
\text { the total }\end{array}$ \\
\hline Albania & 4.7 & 0.3 & 6 \\
\hline Belgium & 24.3 & 4.3 & 18 \\
\hline Bosnia and Herzegovina & 5.8 & 0.2 & 3 \\
\hline Bulgaria & 4.9 & 0.1 & 3 \\
\hline Channel Islands & na & na & na \\
\hline Croatia & 16.1 & 1.5 & 10 \\
\hline Denmark & 22.6 & 3.5 & 15 \\
\hline Faroe Islands & na & na & na \\
\hline France & 34.0 & 7.6 & 22 \\
\hline Germany & 14.5 & 0.5 & 4 \\
\hline Greece & 21.0 & 1.0 & 5 \\
\hline Iceland & 90.4 & 3.1 & 3 \\
\hline Ireland & 22.1 & 2.3 & 10 \\
\hline Isle of Man & na & na & na \\
\hline Italy & 24.8 & 4.2 & 17 \\
\hline Lithuania & 41.4 & 0.2 & 1 \\
\hline Montenegro $^{3}$ & 9.7 & 0.7 & 7 \\
\hline Netherlands & 21.2 & 0.7 & 3 \\
\hline Norway & 51.6 & 0.7 & 1 \\
\hline Portugal & 55.8 & 3.6 & 6 \\
\hline Romania & 4.9 & 0.0 & 1 \\
\hline Serbia and Montenegro ${ }^{4}$ & 3.7 & 0.1 & 2 \\
\hline Slovenia & 9.5 & 0.7 & 7 \\
\hline Spain & 42.7 & 6.2 & 14 \\
\hline Sweden & 31.5 & 0.7 & 2 \\
\hline Ukraine & 15.2 & 0.3 & 2 \\
\hline United Kingdom & 20.3 & 1.2 & 6 \\
\hline European average & 24.7 & 1.8 & 7 \\
\hline
\end{tabular}

${ }^{1}$ Data of "fish, seafood + (total)" from the FAO Food Balance Sheets.

${ }^{2}$ Data of "Molluscs, Other" from the FAO Food Balance Sheets.

${ }^{3}$ Average for the period 2006-2010.

${ }^{4}$ Average for the period 2001-2005. 
Table 2. Average annual production of marine mollusks in European countries (2001-2010)

\begin{tabular}{|c|c|c|c|c|c|}
\hline Country & $\begin{array}{l}\text { Total marine } \\
\text { mollusks } \\
\text { production } \\
\text { (tonnes) }\end{array}$ & $\begin{array}{l}\text { Marine } \\
\text { mussel } \\
\text { production (\% } \\
\text { of total } \\
\text { production) }\end{array}$ & $\begin{array}{l}\text { Marine oyster } \\
\text { production }(\% \\
\text { of total } \\
\text { production })\end{array}$ & $\begin{array}{l}\text { Marine clam, } \\
\text { cockle, and } \\
\text { arkshell } \\
\text { production (\% } \\
\text { of total } \\
\text { production) }\end{array}$ & $\begin{array}{l}\text { Marine } \\
\text { aquaculture } \\
\text { mollusks } \\
\text { production } \\
(\%)\end{array}$ \\
\hline Albania & 255 & 99 & 0 & 0 & 99 \\
\hline Belgium & 677 & na & na & na & 0 \\
\hline $\begin{array}{l}\text { Bosnia and } \\
\text { Herzegovina }\end{array}$ & 17 & 58 & 42 & 0 & 100 \\
\hline Bulgaria & 380 & 5 & 0 & 0 & 2 \\
\hline Channel Islands & 470 & 0 & 52 & 0 & 52 \\
\hline Croatia & 575 & 92 & 3 & 0 & 94 \\
\hline Denmark & 62265 & 99 & 0 & 0 & 0 \\
\hline Faroe Islands & 1868 & na & na & na & 0 \\
\hline France & 185899 & 22 & 61 & 0 & 83 \\
\hline Germany & 22313 & 93 & 0 & 1 & 93 \\
\hline Greece & 11367 & 85 & 5 & 0 & 58 \\
\hline Iceland & 4677 & 0 & 0 & 1 & 0 \\
\hline Ireland & 14381 & 71 & 6 & 0 & 68 \\
\hline Isle of Man & 3142 & 0 & 0 & 0 & 0 \\
\hline Italy & 87074 & 57 & 1 & 4 & 49 \\
\hline Lithuania & $<1$ & na & na & na & 0 \\
\hline Montenegro & 1 & na & na & na & 0 \\
\hline Netherlands & 104387 & 84 & 1 & 1 & 85 \\
\hline Norway & 4447 & 13 & 0 & 0 & 12 \\
\hline Portugal & 6428 & 1 & 13 & 8 & 52 \\
\hline Romania & $<1$ & 100 & 0 & 0 & 0 \\
\hline Serbia and Montenegro & $<1$ & 100 & 0 & 0 & 100 \\
\hline Slovenia & 63 & 99 & 0 & 0 & 99 \\
\hline Spain & 161846 & 87 & 1 & 1 & 89 \\
\hline Sweden & 785 & 98 & 2 & 0 & 97 \\
\hline Ukraine & 143 & 69 & 0 & 0 & 20 \\
\hline United Kingdom & 43812 & 24 & 2 & 4 & 10 \\
\hline European total & 717726 & 61 & 9 & 1 & 58 \\
\hline
\end{tabular}

Source: Own calculation based on FAO Fishstat data. 
Table 3. Average annual trade volume and value of marine mollusks in European countries $(2001-2010)^{1}$

\begin{tabular}{|c|c|c|c|c|c|c|}
\hline & \multicolumn{3}{|c|}{ Trade quantity (tonnes) (export - import) } & \multicolumn{3}{|c|}{ Trade value (000 USD) (export - import) } \\
\hline Country & Mussels & Oyster & $\begin{array}{l}\text { Clam, } \\
\text { cockle, and } \\
\text { arkshell }\end{array}$ & Mussels & Oyster & $\begin{array}{l}\text { Clam, } \\
\text { cockle, and } \\
\text { arkshell }\end{array}$ \\
\hline Albania & -2 & -1 & 0 & -5 & -3 & 0 \\
\hline Belgium & -26653 & -2101 & -123 & -92931 & -10381 & -479 \\
\hline $\begin{array}{l}\text { Bosnia and } \\
\text { Herzegovina }\end{array}$ & -9 & 0 & 0 & -39 & -1 & 0 \\
\hline Bulgaria & -47 & -4 & -2 & -167 & -22 & -11 \\
\hline Channel Islands & 0 & 0 & 0 & 0 & 0 & 0 \\
\hline Croatia & -183 & -1 & -1 & -593 & -7 & -2 \\
\hline Denmark & 24960 & 651 & -1 & 40271 & 4751 & 9 \\
\hline Faroe Islands & -105 & 7 & 0 & -201 & 63 & 0 \\
\hline France & -51576 & 3908 & 1252 & -88178 & 24637 & 11374 \\
\hline Germany & -15362 & -670 & -23 & -10587 & -3117 & -69 \\
\hline Greece & 13447 & -23 & 236 & 7634 & -109 & 1208 \\
\hline Iceland & -8 & 0 & 87 & -61 & 0 & 406 \\
\hline Ireland & 16906 & 2380 & 1 & 35927 & 8634 & 7 \\
\hline Isle of Man & 0 & 0 & 0 & 0 & 0 & 0 \\
\hline Italy & -28769 & -5920 & 666 & -43290 & -18767 & 4978 \\
\hline Lithuania & -42 & -22 & 0 & -123 & -56 & 0 \\
\hline Montenegro & -4 & 0 & 0 & -26 & -1 & 0 \\
\hline Netherlands & 21551 & 1790 & -65 & 98457 & 5954 & -151 \\
\hline Norway & 1294 & -32 & 0 & 682 & -262 & 0 \\
\hline Portugal & -2057 & 108 & -3940 & -6055 & 150 & -8030 \\
\hline Romania & -99 & -10 & -5 & -401 & -65 & -43 \\
\hline $\begin{array}{l}\text { Serbia and } \\
\text { Montenegro }\end{array}$ & -12 & -2 & 0 & -45 & -1 & 0 \\
\hline Slovenia & -140 & -6 & 0 & -437 & -34 & -3 \\
\hline Spain & 24893 & -2928 & -11759 & 12645 & -12533 & -43096 \\
\hline Sweden & -605 & -163 & -1 & -2671 & -510 & -1 \\
\hline Ukraine & -222 & -43 & 0 & -471 & -550 & 0 \\
\hline United Kingdom & 8939 & 487 & -7 & -3676 & 1791 & -22 \\
\hline European total & -13904 & -2596 & -13683 & -54341 & -436 & -33926 \\
\hline
\end{tabular}

${ }^{1}$ Data of "mussels, oysters, clams, cockles and arkshells prepared/preserved, live/fresh/chilled, other than live/fresh/chilled" from FAO Fishstat data. Own calculation. 
Figure 1. Estimated annual economic loss in Europe in the year 2100 due to damage on mollusk production under ocean acidification

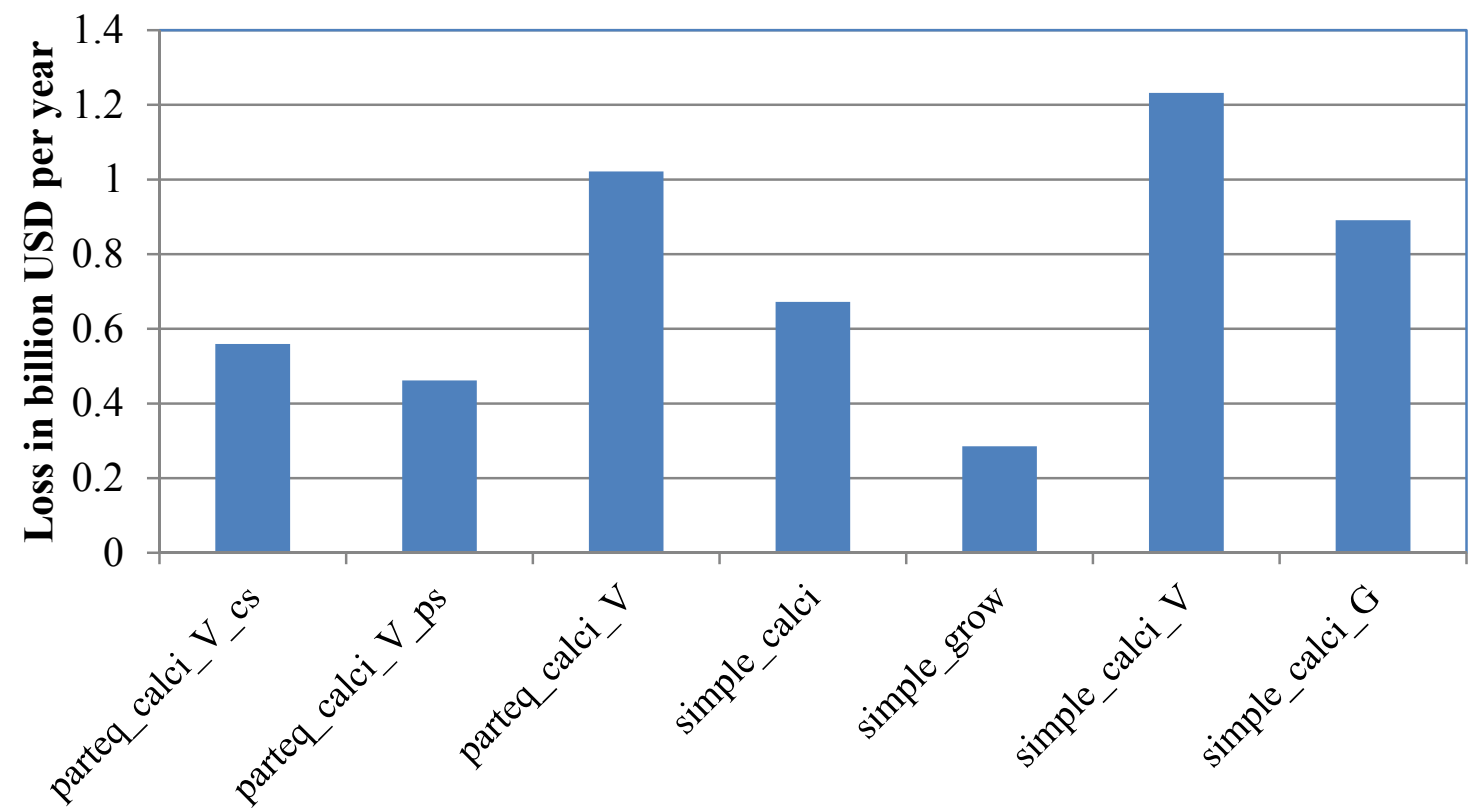

\section{Note:}

parteq calci V cs Acidification consumer surplus loss based on calcification loss and Van Vuuren 2100 income, total mollusk fisheries

parteq_calci_V_ps Acidification producer surplus loss based on calcification loss and Van Vuuren 2100 income, total mollusk fisheries

parteq_calci_V Net total loss based on calcification loss and Van Vuuren 2100 income, total mollusk fisheries

simple_calci Without price and income effects based on calcification loss, total mollusk fisheries

simple_grow Without price and income effects based on growth loss, total mollusk fisheries

simple_calci_V Without price effects based on calcification loss and Van Vuuren 2100 income, total mollusk

fisheriessimple_calci_G Without price effects based on calcification loss and Gaffin 2100 income, total mollusk fisheries 
Figure 2. Estimated annual economic loss in selected European countries in the year 2100 due to damage on mollusk production under ocean acidification

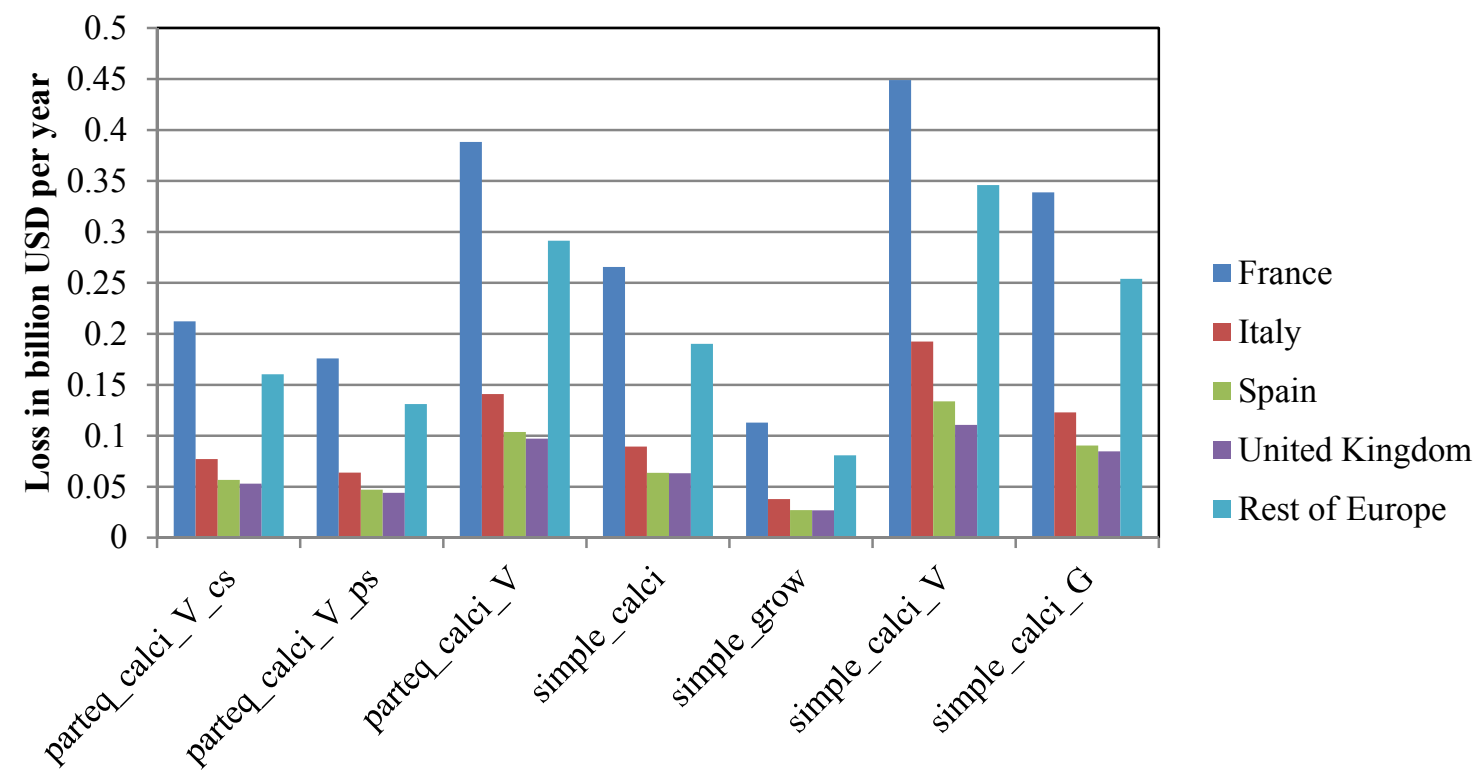

\section{Note:}

parteq calci V cs Acidification consumer surplus loss based on calcification loss and Van Vuuren 2100 income, total mollusk fisheries

parteq_calci_V_ps Acidification producer surplus loss based on calcification loss and Van Vuuren 2100 income, total mollusk fisheries

parteq_calci_V Net total loss based on calcification loss and Van Vuuren 2100 income, total mollusk fisheries

simple_calci Without price and income effects based on calcification loss, total mollusk fisheries

simple_grow Without price and income effects based on growth loss, total mollusk fisheries

simple_calci_V Without price effects based on calcification loss and Van Vuuren 2100 income, total mollusk

fisheriessimple_calci_G Without price effects based on calcification loss and Gaffin 2100 income, total mollusk fisheries 
Figure 3. Estimated annual economic loss in Europe in the year 2100 due to damage on mollusk production under ocean acidification for selected species groups (parteq_calci_V scenario)

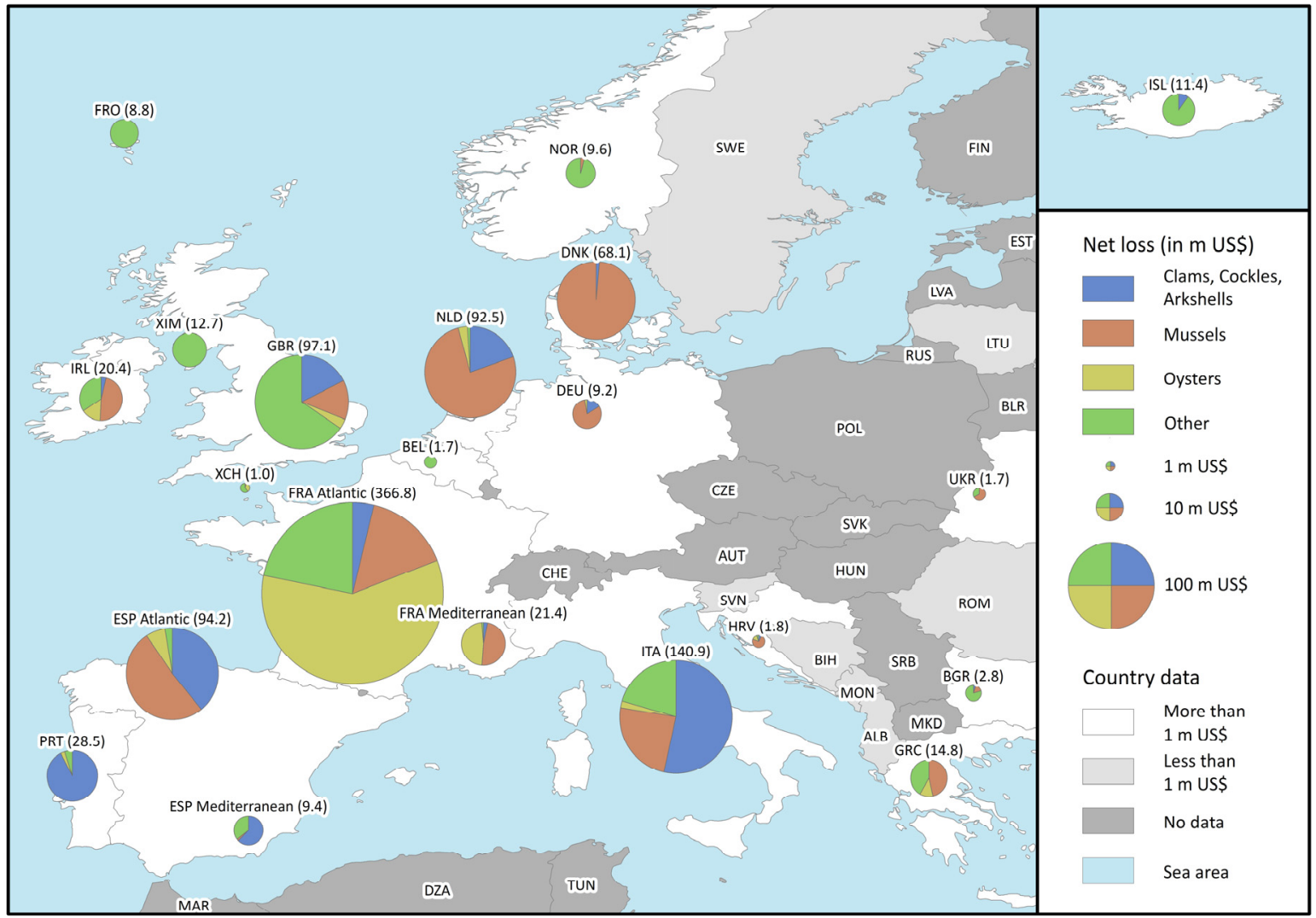


Figure 4. Estimated annual economic loss in subnational regions of Europe in the year 2100 due to damage on mussel production under ocean acidification (parteq_calci_V scenario)

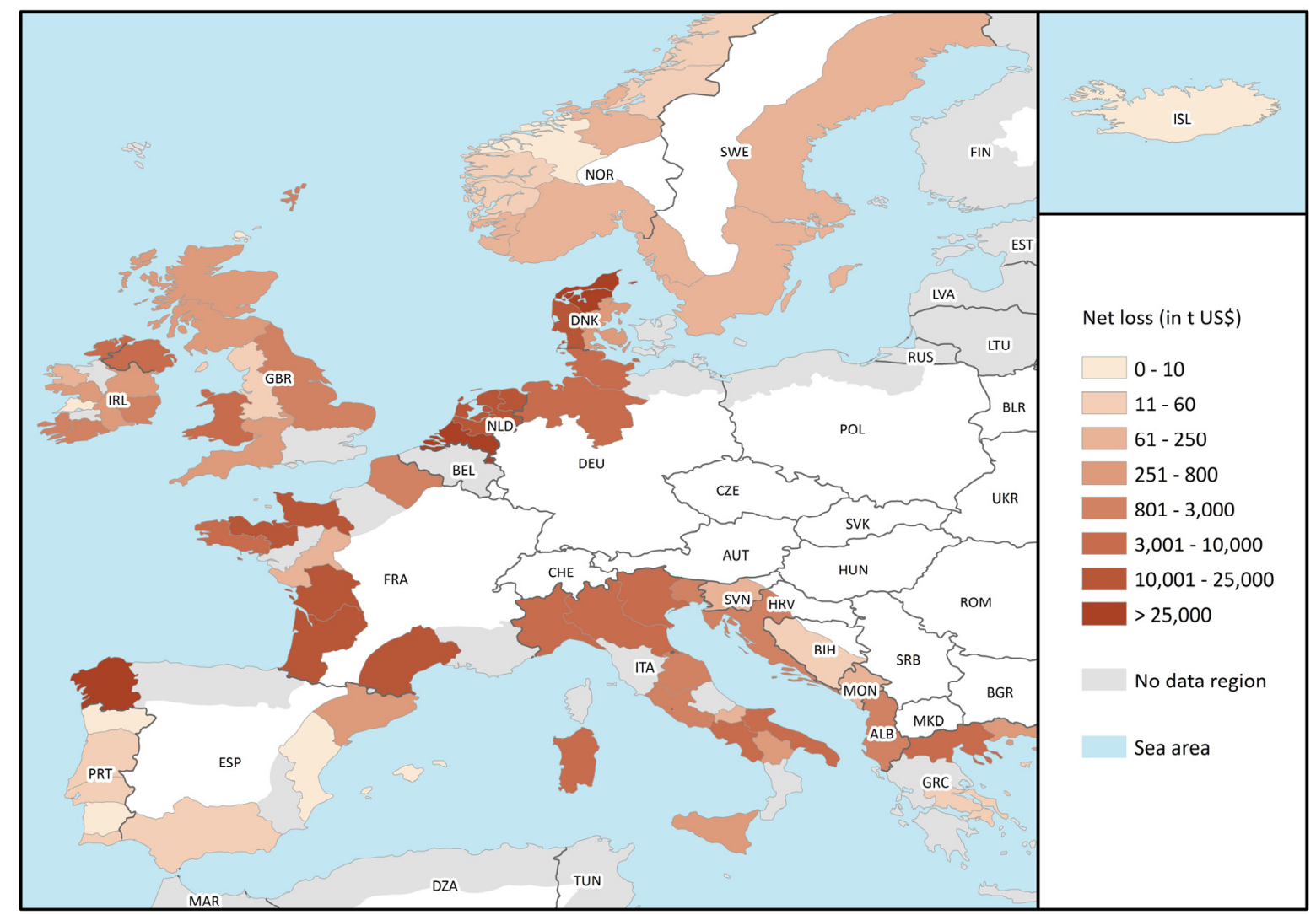


Figure 5. Estimated annual economic loss in subnational regions of Europe in the year 2100 due to damage on oyster production under ocean acidification (parteq_calci_V scenario)

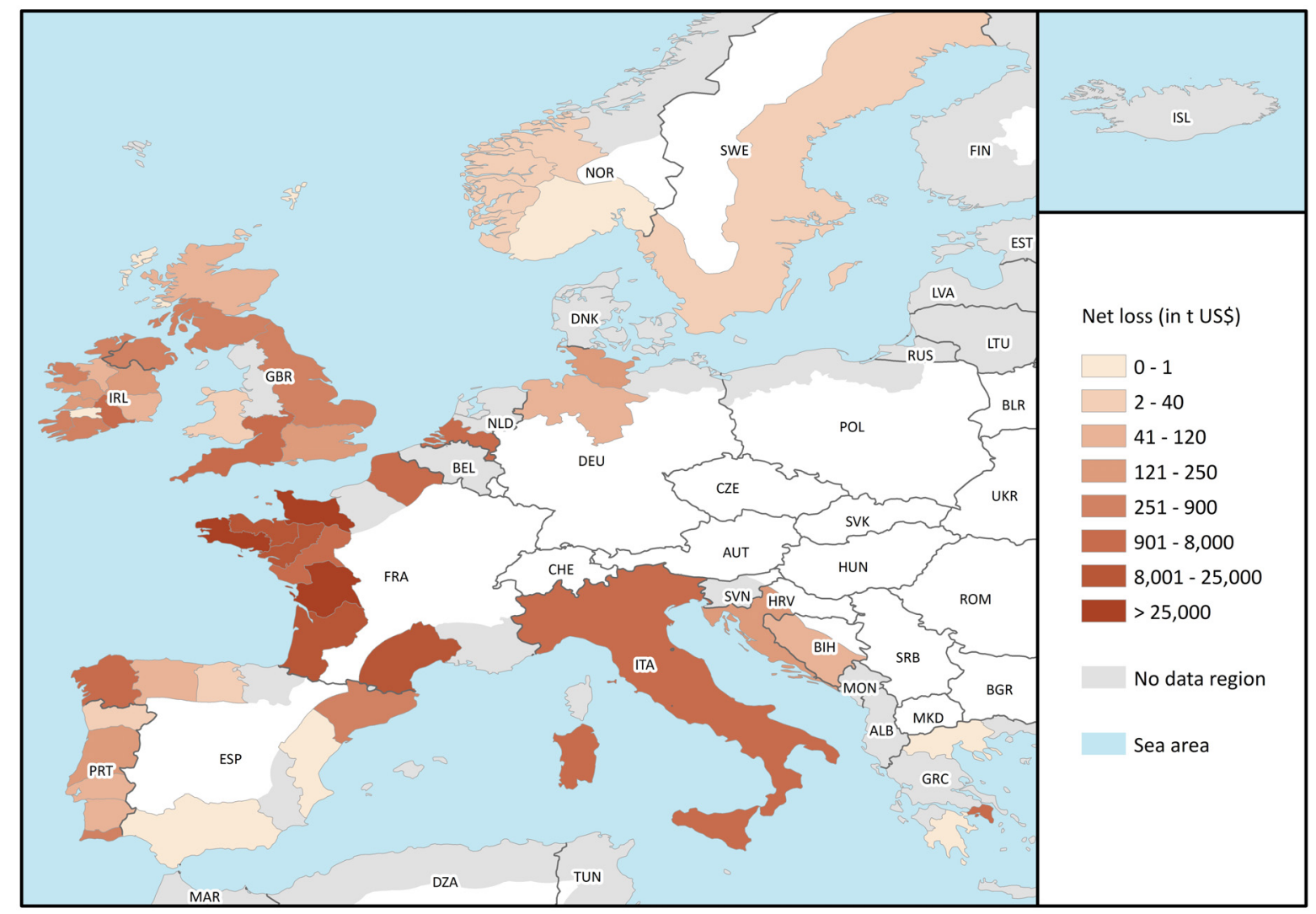




\section{Appendix}

Table A1. Employment in sub-sectors of fisheries in European countries (number of workers in full-time equivalent, or FTE)

\begin{tabular}{|c|c|c|c|c|c|}
\hline Country & $\begin{array}{c}\text { Capture } \\
\text { fisheries (total) }\end{array}$ & $\begin{array}{c}\text { Processing } \\
\text { (secondary } \\
\text { employment of } \\
\text { fisheries) }\end{array}$ & Aquaculture & $\begin{array}{c}\text { Shellfish } \\
\text { aquaculture }\end{array}$ & Note \\
\hline Albania & 5200 & 800 & ND & ND & FAO 2002 data \\
\hline Belgium & 342 & ND & ND & ND & \\
\hline Bulgaria & 1668 & 317 & 270 & ND & \\
\hline Croatia & 3720 & ND & ND & ND & FAO 2008 data \\
\hline Denmark & 1661 & 3235 & 299 & 2 & \\
\hline France & 7447 & 15662 & 10658 & 9142 & \\
\hline Germany & 1258 & 6509 & $1000^{2}$ & 17 & \\
\hline Greece & 30196 & 2265 & $5559^{2}$ & ND & $\begin{array}{l}\text { Capture figure is } \\
\text { from FAO }\end{array}$ \\
\hline Iceland & 4300 & $3100^{1}$ & ND & 0 & FAO 2008 data \\
\hline Ireland & 3166 & 2829 & 958 & 765 & \\
\hline Italy & 20599 & 5517 & 2116 & 1812 & \\
\hline Lithuania & 575 & 3699 & 0 & 0 & \\
\hline Montenegro & 159 & 17 & 36 & 0 & \\
\hline Netherlands & 1768 & 2537 & 255 & 255 & \\
\hline Norway & 9640 & $32350^{1}$ & 3930 & ND & FAO 2008 data \\
\hline Portugal & 17188 & 6913 & 1749 & 1425 & \\
\hline Romania & 28 & 1178 & 1047 & 0 & \\
\hline Slovenia & 77 & 351 & 28 & 15 & \\
\hline Spain & 32194 & 17702 & 6639 & 4159 & \\
\hline Sweden & 974 & 1837 & 263 & 21 & \\
\hline Ukraine & 31000 & $10000^{1}$ & 12000 & ND & FAO 2001 data \\
\hline United Kingdom & 7192 & 18572 & 2671 & ND & \\
\hline
\end{tabular}

Data sources:

Unless otherwise noted, the data are the 2011 figures from the Annual Economic Report on the EU Fishing Fleet, the Economic Performance of the EU Fish Processing Industry, and the Economic Performance of the EU Aquaculture Sector.

${ }^{1}$ Including other forms of secondary employment (distributions, etc.).

${ }^{2}$ In number (not in FTE). 
Figure A1. Change of pH-value between 1990-2009 and 2080-2099 (RCP 8.5)

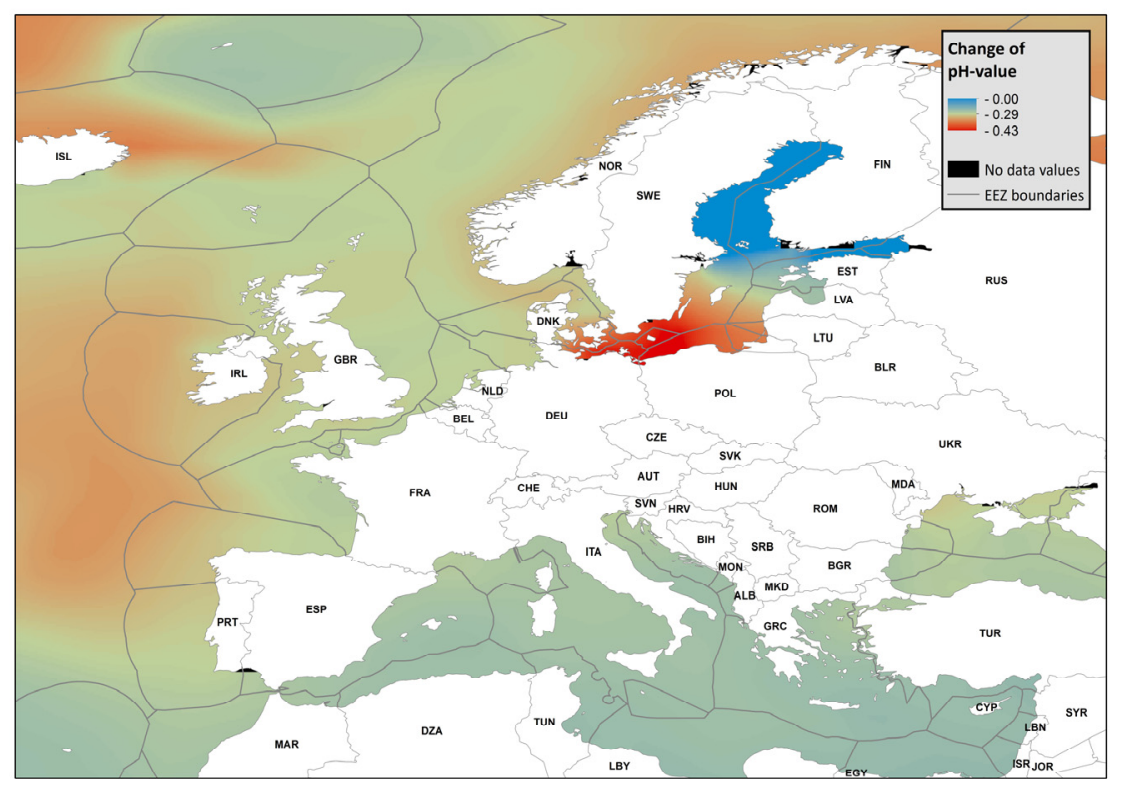

Note: The projected $\mathrm{pH}$-changes in European waters for the RCP 8.5 scenario was simulated by fully coupled Earth System Models for CMIP5/AR5. We averaged over the model output and interpolated to a 1/8 x 1/8 degree grid level (originally $1 \mathrm{x} 1$ degree grid level). Since the land mask differs for different models, the number of data points differs across grid cells. 
Figure A2. Changes in producer and consumer surpluses considered in analysis

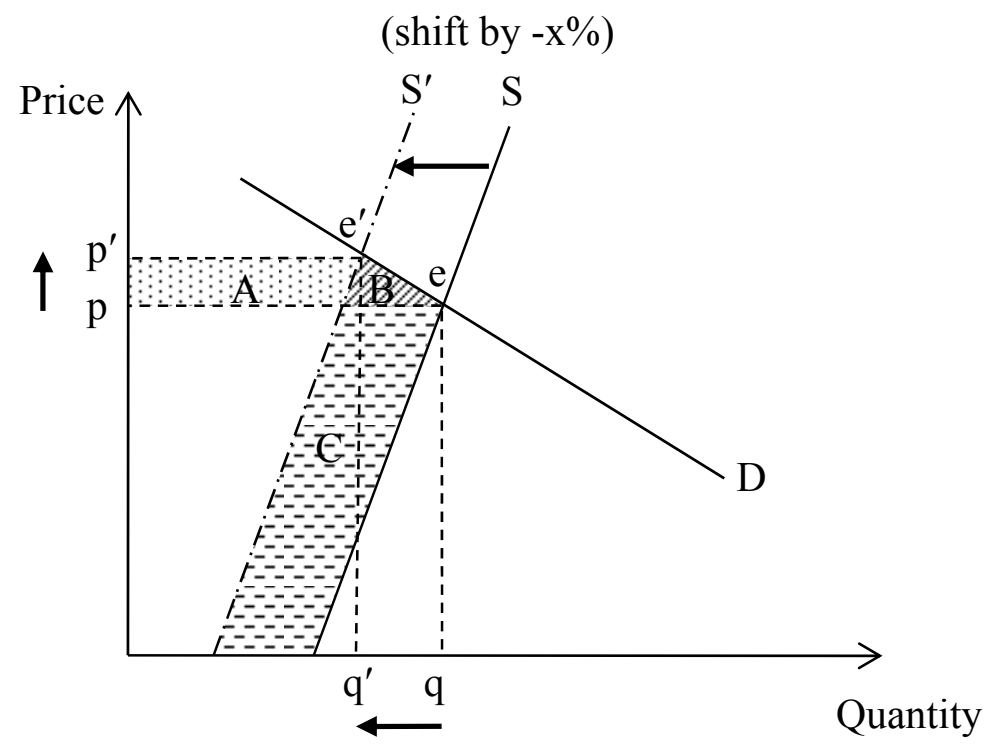

The graph illustrates the demand and supply curves of mollusk production. The equilibrium point (e) of mollusk production without acidification is located at the intersection of the demand $(D)$ and supply $(S)$ curves. The slopes of the supply and demand curves could be numerically determined by using empirical assessments of supply and demand elasticities of mollusks. Introduced as an exogenous shock, acidification raises the unit production costs of mollusk production and shifts the supply curve leftward $\left(S \rightarrow S^{\prime}\right)$. The producers offset a part of revenue loss from the increase of unit production costs by raising the price $\left(p \rightarrow p^{\prime}\right)$. As a result, the equilibrium point moves from $e$ to $e^{\prime}$. Effective costs of ocean acidification for the consumers are the combination of costs from the loss in the consumed quantity $\left(q \rightarrow q^{\prime}\right)$ and the increase in the price. $C$ - $A$ in the graph represents the loss of producer surplus due to acidification, whereas $A+B$ corresponds to the loss of consumer surplus. The net total loss for the economy is $B+C$. The same analytical approach has been used by Narita et al. (2012). 
Figure A3. Estimated annual economic loss in Europe in the year 2100 due to damage on mollusk production under ocean acidification for selected species groups

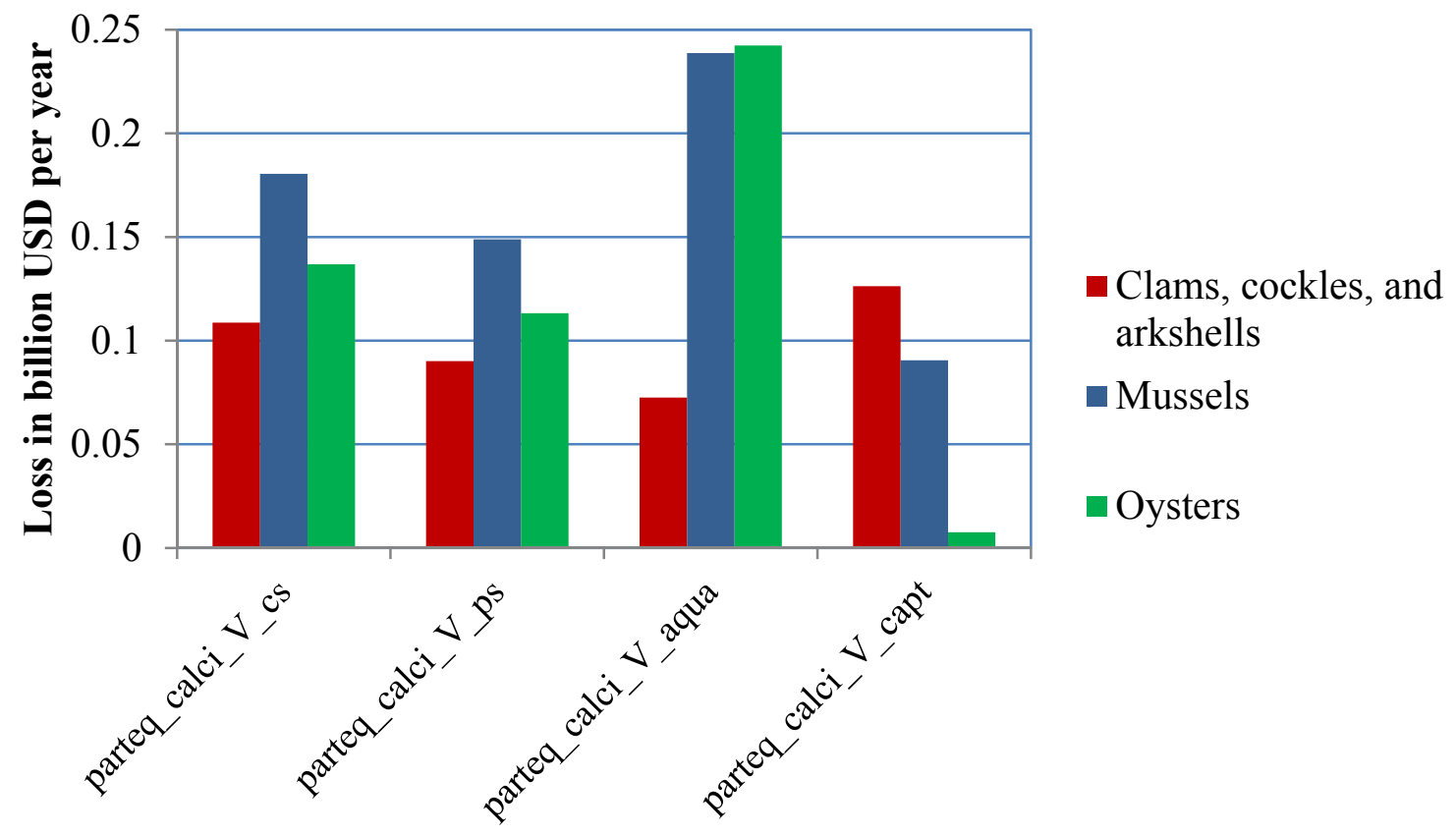

\section{Note:}

parteq calci V cs Consumer surplus loss based on calcification loss and Van Vuuren 2100 income, total mollusk fisheries parteq_calci_V_ps Producer surplus loss based on calcification loss and Van Vuuren 2100 income, , total mollusk fisheries parteq_calci_V_aqua parteq_calci_V_capt Net total loss based on calcification loss and Van Vuuren 2100 income, aquaculture Net total loss based on calcification loss and Van Vuuren 2100 income, capture fisheries 